\title{
PENERAPAN GAYA MENGAJAR RESIPROKAL TERHADAP HASIL PEMBELAJARAN PASSING BAWAH PERMAINAN BOLA VOLI PADA SISWA
}

\author{
APPLICATION OF RECIPROCAL TEACHING STYLE ON THE LEARNING \\ OUTCOMES OF VOLLEYBALL PASSING GAMES
}

\author{
SONI SONJAYA
}

SMP Negeri 2 Cikeusal Kab Serang

\begin{abstract}
Abstrak
Berdasarkan hasil diatas pada siklus pertama siswa cukup antusias dalam mengikuti pembelajaran passing bawah bola voli. Sesuai dengan refleksi, harapan dari peneliti $80 \%$ siswa aktif, termotivasi, serta antusias dalam mengikuti kegiatan pembelajaran. Sehingga pada tahap siklus kedua peneliti berhasil memperbaiki pendekatan pembelajaran dengan memotivasi siswa sesuai dengan kondisi siswa pada saat itu, hasilnya adalah 32 siswa aktif dalam mengikuti pembelajaran passing bawah bola voli, 4 siswa bersikap kadang aktif dan kadang acuh, serta 2 siswa tidak aktif atau pasif. Berdasar hasil belajar siswa pada siklus pertama nilai rata-rata kelas pembelajaran passing bawah bola voli adalah 62 dan hasil belajar siswa pada siklus kedua adalah 77 .
\end{abstract}

Kata Kunci: Gaya Mengajar Resiprokal, Pembelajaran Passing Bawah

\begin{abstract}
Based on the results above in the first cycle the students were quite enthusiastic in participating in learning to pass under volleyball. In accordance with reflection, the expectations of researchers $80 \%$ of students are active, motivated, and enthusiastic in participating in learning activities. So that in the second cycle phase the researchers succeeded in improving the learning approach by motivating students according to the conditions of the students at that time, the result was 32 active students participating in volleyball passing, 4 students were sometimes active and sometimes indifferent, and 2 students were inactive or passive. Based on student learning outcomes in the first cycle the average value of passing volleyball learning classes is 62 and student learning outcomes in the second cycle are 77.
\end{abstract}

Keywords: Reciprocal Teaching Style, Lower Passing Learning

\section{PENDAHULUAN}

Konsep

pembelajaran

pendidikan jasmani adalah salah satu bentuk pencapaian tujuan pendidikan secara keseluruhan, namun pada kenyataannya tujuan yang telah ditetapkan dalam perencanaan tidak tercapai setelah guru melaksanakan pembelajaran. Menurut Syarifudin (2000: 4) salah satu penyebabnya adalah kurang kompetennya guru pendidikan jasmani dalam memilih 
dan menentukan metode

dilakukan oleh setiap orang, pembelajaran, sehingga tidak jarang dikarenakan dalam permainan bola proses pembelajaran berlangsung dengan suasana tidak kondusif dan kurang menarik.

Berdasarkan kendala yang ada, peneliti berasumsi bahwa guru pendidikan jasmani dan kesehatan perlu mengupayakan segala kemampuan yang dimilikinya untuk dapat mengantisipasi segala hambatan yang diperkirakan akan muncul dalam proses pembelajaran dengan berbagai usaha sehingga mengarah pada pencapaian tujuan dan sasaran yang dikehendaki dalam proses pembelajaran. Usaha-usaha yang dapat peneliti asumsikan itu diantaranya menciptakan suasana belajar yang menarik minat siswa untuk belajar lebih giat, mempergunakan waktu seefektif mungkin dan yang paling penting adalah mempergunakan metode mengajar yang tepat.

Permainan bola voli, sebagai salah satu materi wajib dalam pendidikan jasmani dan kesehatan merupakan salah satu cabang olahraga yang banyak peminatnya di Indonesia, akan tetapi peneliti melihat bahwa permainan bola voli merupakan suatu permainan yang kompleks yang tidak mudah untuk 
menitik beratkan kepada proses umpan balik atau feed back. Pendekatan ini memiliki asumsi bahwa informasi tentang hasil belajarnya berdasarkan tindakan yang dilakukan oleh pengamat. Dalam metode ini, informasi yang menyebabkan perbaikan disebut umpan balik negatif sedangkan informasi yang justru memantapkan hasil belajarnya disebut umpan balik positif.

Oleh karena itu, peneliti akan meneliti kebenaran dari asumsi tersebut pada seberapa besar pengaruh metode resiprokal dalam mengoptimalkan dan meningkatkan hasil belajar pembelajaran passing bawah dalam permainan bola voli yang dilaksanakan oleh para siswa kelas 7 di SMP Negeri 2 Cikeusal Kabupaten Serang Banten.

\section{KAJIAN TEORETIK}

Belajar mengajar merupakan inti dari proses pendidikan formal secara keseluruhan dengan guru sebagai pemegang peranan utama. Diantara belajar dan mengajar memiliki pengertian dan konsep yang berbeda akan tetapi keduanya merupakan komponen yang saling terkait antara yang satu dengan yang lain. Sebagaimana yang dikemukakan oleh
Balow dan Skinner (Rusyam, 1993: 6) mendefinisikan bahwa belajar sebagai suatu proses yang ditandai dengan perubahan pada diri seseorang sebagai hasil dari pengalaman dan latihan. Perubahan tersebut tentunya berefek pada bertambahnya pengetahuan, pemahaman, sikap dan kecakapan serta kemampuan seseorang.

Menurut Syarifudin (1994: 15) mengemukakan pengertian mengajar sebagai berikut: mengajar pada hakikatnya adalah suatu kegiatan yang dilakukan oleh seseorang atau tim (guru/pendidik) dalam usahanya untuk membantu seseorang atau kelompok orang yang sedang belajar agar memperoleh berbagai pengalaman yang diharapkan. Sujana (1994: 5) berpendapat bahwa mengajar adalah suatu proses mengatur, mengorganisasikan lingkungan yang ada di sekitar siswa sehingga dapat menumbuhkan dan mendorong siswa melakukan proses belajar. Pada tahap berikutnya mengajar adalah proses memberikan bimbingan atau bantuan kepada siswa dalam melakukan proses belajar. Dari pengertian-pengertian di atas tentang belajar mengajar, jelas menunjukan adanya hubungan antara belajar dengan mengajar yang 
merupakan suatu proses adanya hubungan untuk mempunyai suatu tujuan berupa pengetahuan pada anak didik sebagai objek yang diajarkan. Dengan kata lain bahwa proses belajar mengajar adalah komponen pengajaran yang diorganisasikan secara sistematik tujuannya untuk membentuk atau merubah sikap dan nilai-nilai tingkah laku, kemampuan serta keterampilan.

Mosston dan Asworth (1994: 3) berpendapat bahwa strategi pengajaran seperti halnya strategi perang, yang merupakan suatu cara untuk menyiasati sistem pengajaran, sehingga tujuan proses belajar mengajar dapat tercapai dengan efektif dan efisien. Selanjutnya dikemukakan spektrum pendekatan mengajar yang dipilih, merupakan jembatan penghubung antara siswa dan materi pelajaran. Spektrum pengajaran merupakan konsepsi teoritis serta rancangan, pelaksanaan dari pendekatan pengajaran yang akan dipilih oleh seorang guru. Dengan menggunakan spektrum pengajaran akan dapat memberikan kemampuan yang diperlukan oleh setiap guru dalam pemilihan pendekatan pengajaran tertentu, yang pada akhirnya akan membekali guru dengan pengetahuan mengenai langkah-langkah untuk mencapai keberhasilan dalam pelaksanaan proses belajar mengajar.

Berdasarkan anatomi pendekatan dari Mosston, dalam upaya mengimplementasi dan mengaplikasikan spektrum pendekatan mengajar, Niel J. Dougherthy mengemukakan enam pendekatan mengajar, yaitu pendekatan komando (command style) ; (2) pendekatan latihan (task style); (3) pendekatan resiprokal (reciprocal style); (4) pendekatan kelompok kecil (small group style); (5) pendekatan penemuan terpimpin (guided discovery style); pendekatan pemecahan masalah (problem solving style).

Jadi yang dimaksud pendekatan mengajar adalah kemampuan menggunakan berbagai cara untuk menyiasati sistem pengajaran sehingga tujuan proses belajar mengajar dapat tercapai dengan efektif dan efisien. Secara singkat, tujuan proses belajar mengajar adalah untuk mempengaruhi siswa agar dapat belajar atau membelajarkan siswa mencapai tujuan seperti yang diharapkan, banyak faktor penting yang harus diperhatikan oleh seorang guru salah satunya guru harus mampu mengelola proses belajar 
mengajar maka dimungkinkan semua komponen proses belajar mengajar akan mampu berinteraksi dan bekerja sama satu sama lainnya secara terpadu dan fungsional sehingga proses belajar mengajar akan efektif dan efisien.

Di dalam suatu proses pembelajaran dihadapkan pada suatu penilaian atau mengevaluasi penguasaan materi pada siswanya, sejauh mana tingkat penguasaan dan pemahaman mereka terhadap materi yang diberikan oleh instruktur maupun gurunya. Dengan adanya penilaian tersebut dapat diketahui tolak ukur keberhasilan prestasi siswa. Soedijarto (Sujana, 2001: 61) mengemukakan hasil belajar merupakan tingkat penguasaan yang dapat dicapai oleh sisiwa dalam mengikuti proses belajar mengajar sesuai dengan kebutuhan akan tujuan yang telah ditetapkan. Hasil belajar dapat dilihat dari perubahan tingkah laku siswa sesuai dengan tujuan yang diinginkan dan ditetapkan. Soedijarto (Sujana, 2001: 64) juga mengatakan tujuan belajar pada intinya adalah ingin mendapatkan pengetahuan dan keterampilan yang sesuai dengan ketiga ranah yaitu ranah kognitif, ranah afektif dan ranah psikomotorik.
Hasil belajar diukur langsung dengan adanya evaluasi belajar (tes) dan evaluasi belajar terhadap proses yang dilakukan pada kegiatan belajar karena penilaian akhir gerak siswa adalah dengan angka-angka atau penilaian yang diberikan oleh gurunya. Dengan demikian kegiatan belajar akan menimbulkan hasil belajar artinya melalui kegiatan belajar akan menambah pengalaman, pemahaman dan merubah perilaku seseorang terhadap sesuatu yang diwujudkan dalam hasil belajar. Perubahan yang terjadi pada seorang individu memiliki hasil yang bervariasi baik dari sifat maupun jenisnya. Tidak semua perubahan yang terjadi dalam diri seseorang merupakan perubahan dalam arti belajar.

Dari beberapa definisi hasil belajar yang telah dikemukakan sebelumnya maka dapat dideskripsikan bahwa hasil belajar adalah tingkat kemampuan yang didapatkan seseorang setelah mengikuti proses belajar. Kemampuan yang dimaksud bukan hanya mencakup kemampuan intelektual saja. Kemampuan yang didapatkan juga mencakup kemampan seseorang dalam sikap serta ketrampilan. 
Permainan bola voli merupakan suatu permainan yang kompleks yang tidak mudah dilakukan oleh setiap orang, sebab dalam permainan bola voli dibutuhkan koordinasi gerak yang benar-benar bisa diandalkan untuk melakukan semua gerakan yang ada dalam permainan bola voli. Dalam permainan bola voli teknik dasar yang harus dikuasai diantaranya servis, passing atas, passing bawah dan smash, hal ini merupakan modal dasar untuk melakukan bentuk permainan bola voli. Usaha untuk meningkatkan keterampilan bermain bola voli terutama tentang teknik passing bawah merupakan hal yang penting sebab untuk menerima bola baik yang dipukul keras, mendatar dan menerima smesh, atau meneruskan operan bola yang rendah dan mendatar, baik dari kawan maupun lawan sangat tepat apabila bisa menggunakan teknik passing bawah, karena teknik passing bawah merupakan satu-satunya cara yang mudah untuk menerima pukulan maupun operan.

Posisi awal untuk melakukan passing bawah adalah berdiri dengan posisi melangkah, dengan kaki depan yang berlawanan dengan tangan yang akan memukul bola. Tangan yang akan memukul bola harus lurus dan kencang, sikut jangan bengkok sampai bola terpukul. Memainkan bola dengan sisi dalam lengan bawah merupakan teknik bermain yang cukup penting. Kegunaan teknik lengan bawah antara lain (Ahmadi, 2007: 23) untuk penerimaan bola servis, untuk penerimaan bola dari lawan yang berupa serangan/smash, untuk pengambilan bola setelah terjadi blok atau bola dari pantulan net, untuk menyelamatkan bola yang kadang-kadang terpental jauh di luar lapangan permainan, dan untuk pengambilan bola yang rendah dan mendadak datangnya.

Selain itu, yang perlu ditekankan adalah pendekatan dialogis dalam pembelajaran baik antara guru dengan siswa ataupun siswa dengan siswa. Guru dituntut untuk memiliki kemampuan dialog yang baik serta teliti dan peka dalam mengamati. Pada prosesnya, mungkin saja siswasiswa yang memiliki kecenderungan diam, guru harus melakukan motivasi untuk membangkitkan keaktifan siswa.

\section{METODE PENELITIAN}

Metode penelitian yang digunakan adalah metode Penelitian Tindakan Kelas (Classroom Action Research) dengan pengambilan data 
kualitatif dan kuantitatif, pelaksanaan penelitian melibatkan rekan sejawat sebagai kolaborator. Penelitian Tindakan Kelas ini dilaksanakan di SMP Negeri 2 Cikeusal Kab. Serang Banten. Waktu penelitian dilakukan pada semester ganjil tahun ajaran 2018/2019 pada bulan Agustus 2018 hingga Nopember 2018. Subyek penelitian adalah siswa Kelas 7 di SMP Negeri yang berjumlah 30 orang, terdiri dari 14 orang perempuan dan 16 orang laki-laki. Data yang diperoleh dalam penelitian ini melalui observasi dan pengamatan serta tes hasil belajar siswa yang dituliskan dalam suatu format. Untuk mengecek keabsahan data penelitian, dilakukan oleh peneliti bersama kolaborator.

\section{HASIL PENILITIAN DAN} PEMBAHASAN

Hasil siklus pertama menunjukkan bahwa sebanyak 23 siswa (58\%) siswa Belum mampu melakukan gerakan passing bawah bola voli, atau dengan kata lain belum mencapai batas ketuntasan minimal 11. Sedangkan siswa yang sudah mencapai batas ketuntasan sejumlah 17 siswa (42\%). Hasil refleksi dari siklus pertama ini adalah Siswa memahami dan merasakan penggunaan metode resiprokal yang diterapkan sebagai upaya meningkatkan peningkatan hasil belajar siswa pada materi pembelajaran passing bawah bola voli. Hal ini dapat dilihat dari siswa yang memehami perintah yang diberikan oleh guru, dan melalui pertanyaan yang mereka ajukan serta siswa bisa menemukan sendiri gerakan-gerakan passing bawah bola voli yang membuat siswa merasa nyaman. Dan menjadikan gerakan siswa menjadi lebih baik.

Pada siklus dua menunjukkan bahwa sebanyak 8 siswa (20\%) siswa Belum mampu melakukan gerakan passing bawah bola voli, atau dengan kata lain belum mencapai batas ketuntasan minimal 18. Sedangkan siswa yang sudah mencapai batas ketuntasan sejumlah 32 siswa (80\%), hasil refleksi Siswa memahami dan merasakan penggunaan metode resiprokal yang diterapkan sebagai upaya meningkatkan peningkatan hasil belajar siswa pada materi pembelajaran passing bawah bola voli. Hal ini dapat dilihat dari siswa yang memehami instruksi-instruksi yang diberikan oleh guru. Melalui pertanyaan yang mereka ajukan, mereka bisa menemukan sendiri gerakan-gerakan passing bawah bola 
voli yang membuat mereka merasa nyaman dan menjadikan gerakan mereka menjadi lebih baik. Setelah melihat hasil belajar yang sudah dilakukan guru, dan kolabolator meyakini hasil yang di dapat sudah benar, karena siswa mampu menguasai gerakan passing bawah dan mengerti serta melasanakannya dengan baik dalam setiap pertemuan.

\section{SIMPULAN}

Berdasarkan hasil penelitian yang telah dijelaskan, masalah prosedur penelitian dengan menerapkan metode resiprokal terhadap hasil belajar passing bawah bola voli pada siswa kelas 7 SMPN 2 Cikeusal Kabupaten Serang tahun 2019. Maka hasil yang telah ada dapat disimpulkan hal-hal sebagai berikut:

(1) Perencanaan kegiatan pembelajaran pada siklus pertama dan kedua peneliti konsisten melaksanakan berbagai kegiatan pembelajaran yang disyaratkan untuk menyelenggarakan kegiatan pembelajaran yang baik.

(2) Peneliti memberikan motivasi kepada siswa sesuai dengan rencana pembelajaran, hasilnya adalah 23 siswa aktif, 13 siswa kurang dan 4 siswa pasif.
Berdasarkan hasil diatas pada siklus pertama siswa cukup antusias dalam mengikuti pembelajaran passing bawah bola voli. Sesuai dengan refleksi, harapan dari peneliti $80 \%$ siswa aktif, termotivasi, serta antusias dalam mengikuti kegiatan pembelajaran. Sehingga pada tahap siklus kedua peneliti berhasil memperbaiki pendekatan pembelajaran dengan memotivasi siswa sesuai dengan kondisi siswa pada saat itu, hasilnya adalah 32 siswa aktif dalam mengikuti pembelajaran passing bawah bola voli, 4 siswa bersikap kadang aktif dan kadang acuh, serta 2 siswa tidak aktif atau pasif.

(3) Berdasar hasil belajar siswa pada siklus pertama nilai rata-rata kelas pembelajaran passing bawah bola voli adalah 62 dan hasil belajar siswa pada siklus kedua adalah 77.

\section{DAFTAR PUSTAKA}

Ahmadi, Nuril.Panduan Bola Voli.Solo: Era Pustaka Utama, 2007.

Depdikbud. Suplemen GBPP Pendidikan Jasmani. Jakarta: Depdikbud, 1999. 
Muston, Muska and Asworth, Sara.

Teaching

Physical

Education.New York: Mac

Millian College Publishing

Company Inc, 1994.

Syarifudin. Kunci Sukses

Pengembangan Program

Pendidikan Jasmani.Jakarta:

Ardadizya Jaya, 2000.

Syarifudin, Aip. Dasar-Dasar Di

Dalam Proses Belajar Mengajar

Pendidikan Jasmani. Jakarta:

Bahan Perkuliahan Teori Belajar

Mahasiswa FPOK IKIP, 1994.

Sujana, Nana.Teori-Teori Belajar

Untuk Pengajar.Jakarta: FEUI, 1994.

- Penilaian Hasil ProsesBelajar Mengajar. Bandung: Remaja Rosdakarya, 2001.

Rusyam,Tabrani. Proses Belajar Mengajar Yang Efektif. Bandung: Bina Budaya, 1993.

Yusuf, Syamsu, dkk. Dasar-Dasar Pembinaan Kemampuan Proses Belajar Mengajar. Bandung: CV Andika, 1993. 